\title{
UHMWPE IN TOTAL KNEE ARTHROPLASTY: SUCCESSES \& FAILURES
}

\author{
N. Camacho*", J.M. González Carmona ${ }^{2}$, D.G. Espinosa Arbeláez ${ }^{2}$, G.C. Mondragón- \\ Rodríguez ${ }^{* 2}$, Stephen W. Stafford ${ }^{3}$
}

1: Ph.D., CIDESI - CENTA, National Center for Aeronautical Technologies, Carretera Estatal 200,

Querétaro-Tequisquiapan Km 23 No. 2254, Colón, Querétaro, México

2: Dr., CIDESI - CONMAD, Surface Engineering and Additive Manufacturing Department, Querétaro, Av. Pie de la Cuesta 702, 76125 Querétaro, México.

3: Ph.D., University of Texas System, El Paso, Department of Metallurgical, Materials and Biomedical Engineering, 500 West University Avenue, El Paso, TX, USA, 79968.

*Autor de correspondencia: nayeli.camacho@cidesi.edu.mx, guillermo.mondragon@cidesi.edu.mx

\begin{tabular}{ll}
\hline PALABRAS CLAVE & RESUMEN \\
\hline Polietileno de ultra alto peso & El polietileno de ultra alto peso molecular (UHMWPE por sus siglas en \\
molecular (UHMWPE) & inglés) ha sido el estándar de oro para los reemplazos de rodilla durante \\
Desgaste de UHMWPE & más de cinco décadas. Este biomaterial, utilizado ampliamente en el \\
Materiales compuestos de & sector ortopédico, ha sido constantemente modificado para disminuir su \\
UHMWPE & tasa de desgaste en las prótesis de rodilla. Hoy en día, los reemplazos \\
Reemplazo total de rodilla. & totales de rodilla tienen una tasa de supervivencia del 95 \% después de \\
& 10 años, $88.7 \%$ después de 15, y $82 \%$ después de 25 años. Sin \\
& embargo, la vida útil del componente de UHMWPE a menudo se limita \\
& entre los 15 a 20 años, ya que el daño por desgaste de las superficies del \\
& UHMWPE es inevitable. En pacientes más jóvenes y activos, el \\
& desgaste puede acelerarse, generando una cantidad considerable de \\
& partículas y provocando una falla prematura. Se han reportado \\
& reacciones adversas en el tejido circundante de la articulación de la \\
& rodilla debido a la presencia de estas partículas, especialmente en el \\
& rango de 0.3 a $2 \mu$ m, que a menudo conducen a un aflojamiento aséptico \\
& inducido por osteólisis. Las investigaciones se han centrado en mejorar \\
& la resistencia al desgaste y el rendimiento del UHMWPE. En este \\
& trabajo, se analiza el comportamiento de desgaste y el rendimiento \\
& clínico del UHMWPE desde el punto de vista de la ciencia de los \\
& materiales, así como las modificaciones existentes para mejorar la \\
& resistencia al desgaste de este polímero; la reticulación mediante \\
& irradiación gamma, la estabilización de vitamina E y la incorporación \\
de diferentes nanopartículas.
\end{tabular}




\section{UHMWPE IN TOTAL KNEE ARTHROPLASTY: SUCCESSES \& FAILURES}

\begin{tabular}{ll}
\hline KEYWORDS & ABSTRACT \\
\hline UHMWPE & Ultra-high-molecular weight polyethylene (UHMWPE) has been the \\
UHMWPE wear & gold standard for total knee replacements for over five decades and \\
UHMWPE composites & has been modified continuously to diminish its wear rate. Today, total \\
total knee replacement. & knee replacements have a survival rate of $95 \%$ after ten years, 88.7 \\
& after 15 years, and $82 \%$ after 25 years. However, the UHMWPE \\
& tibial component service life is often limited to 15 to 20 years, since \\
& the wear damage to UHMWPE articulating surfaces is inevitable due \\
& to the constant movement of the femoral component over the \\
& UHMWPE spacer. UHMWPE wear can be highly accelerated for \\
& younger and more active patients, generating a considerable amount \\
& of wear debris and leading to premature failure of the component. \\
& Adverse reactions in the knee joint surrounding tissue have been \\
& reported due to the presence of particles in the range of 0.3 to $2 \mu \mathrm{m}$, \\
& often leading to osteolysis-induced aseptic loosening of the prosthesis \\
& components. Research efforts have focused on improving the wear \\
& resistance and overall performance of this material. This review \\
& discusses the wear behavior and clinical performance of UHMWPE \\
& from a materials science point of view and the existing attempts to \\
& improve the wear resistance of this polymer, such as cross-linking \\
through gamma irradiation, vitamin E-stabilization, and & incorporation of different nanoparticles. \\
\end{tabular}

\section{INTRODUCCIÓN}

Before developing total joint replacements, patients who suffer the burden of end-stage arthritis of the knee had unremitting pain and a significantly decreased functional capacity. Prosthetic knee replacements have dramatically improved the quality of life of millions of people; total knee replacements (TKRs) are designed for partial or complete substitution of the knee joint affected by degenerative diseases such as osteoarthritis and rheumatoid arthritis [1]. Modern TKRs began in the early 1970s in the United States and Europe, when tibiofemoral condylar implants started to be employed to correct severe knee deformities [2].

A total knee arthroplasty (TKA) is a surgical procedure to replace the knee joint. TKA is a very successful treatment for degenerative diseases. The number of TKAs performed globally has seen continuous growth over the years; in 2011, an estimated 1,324,000 primary and revision TKA procedures were performed in only 18 countries [3]. The number of TKAs in the US has doubled in the last ten years $[1,4]$. Conservatively, the number of primary TKA will presumably increase by $143 \%$ by 2050 , reaching about 1.5 million cases/year just in the United States $[5,6]$. Other countries such as Austria have experienced continuous growth of about $13 \%$ annually from 2009 to 2015 [7]. Consequently, the number of TKRs implanted continues to grow every year, making the production of ultra-high molecular weight polyethylene, the current gold standard used in the fabrication of tibial inserts, a multi-billion dollar industry.

Ultra-high molecular weight polyethylene (UHMWPE) is a linear semi-crystalline polymer that has been widely used in industrial and biomedical applications, particularly in the orthopedic field, because of its superior wear resistance, low coefficient of friction, high impact resistance, 
biocompatibility, and high fracture toughness [8-14]. Despite the success of this orthopedic procedure to restore the functional capacity of the knee joint, implants still present many shortcomings leading to premature failure of the individual components, particularly of the UHMWPE tibial insert. Aseptic loosening as a result of wear debris-related osteolysis has been recognized as the primary cause of failure in TKRs [8,13,15-17], limiting the longevity of the implant to 15-20 years [1]. As more TKRs are implanted on increasingly younger patients, rates of osteolysis-induced aseptic loosening are also increasing.

Wear debris will always be produced due to the natural sliding and rolling movements of the knee. Patient factors such as age, gender, height, weight, and knee and body anatomy influence the wear rate of the insert and the operative life of the implant [16]. Additionally, issues related to the adjustment of tibiofemoral alignment and ligament balance increase UHMWPE wear [18]. Produced wear debris causes reduced mobility, increased pain due to biologic response to the debris, mechanical instability due to component loosening, and failure [5], [16]. In extreme cases where the UHMWPE has been completely worn-out, the femoral component starts worn-out, leading to metallosis (or tibial plate break) [18]. The increasing demand for longer-lasting TKRs, particularly for younger and more active patients, has motivated scientists and engineers to improve the performance of UHMWPE [1].

The first attempts to improve the mechanical behavior of the tibial inserts started in the 1970s, blending UHMWPE with carbon fibers [17] and introducing crosslinked polyethylene (XPE) [8]. The composite showed improved hardness and creep resistance; however, characteristic wear modes of matrix-filler interfaces, including fiber pull-out, fiber breakage, crack initiation at the interface, and pit formation, were observed [17,19]. In the 1990s, XPE polyethylene wear performance started to be described as successfully reducing wear rates and osteolysis cases for total hip replacements; nevertheless, the success of reducing wear debris production in TKRs was less clear [19-21]. The second generation, known as highly crosslinked polyethylene (HXLPE), was developed in the 2000s. HXLPE tested in vitro and in vivo reduces polyethylene wear [21]. Several good early clinical results have been reported for knee replacement fabricated with HXLPE, and according to the Annual Report of 2018 of the American Academy of Orthopedic Surgeons, HXLPE was used in primary and revision surgeries performed from 2012 to 2017 in at least $35 \%$ of all registered procedures [22]. The primary strategy to improve crosslinking within the polymer is sterilization at high irradiation doses [20,21]. Moreover, the introduction of vitamin $\mathrm{E}$ as an oxidation stabilizer and post-irradiation heat treatments have helped reduce the oxidative effects of gamma and ion beam irradiation used to crosslink the polymer [21,23-25]. Because these improvements have only partially solved the problem of wear debris-induced osteolysis, more investigations have been carried out.

Nowadays, several reinforcing particles have been blended with UHMWPE to enhance the mechanical performance of this polymer and diminish wear rates, such as micro and nano $\mathrm{ZnO}$ particles [26], talc particles [10], zeolite particles [27], $\mathrm{Zr}$ particles [28], hydroxyapatite [29,30], and carbon-based materials [1]. In particular, carbon nanotubes [12,31-38] and graphene nanoplatelets [3841] have attracted a considerable amount of attention because of its outstanding properties at low particle loading ranging from 0.05 to 1 wt. \%. The characterization of new composites includes the determination of mechanical properties such as tensile 
strength, hardness, impact strength, and modulus of elasticity since the mechanical properties of UHMWPE influence the loadbearing capacity of the material. Additionally, the determination of wear rates, material loss quantity, wear modes affecting the bearing surface, friction coefficient, and shape and size of wear particles [1] under dry and lubricated conditions provide insight into the UHMWPE-composites future clinical performance.

This review describes the advances in the mechanical properties of UHMWPE, summarizes the wear behavior and clinical performance of UHMWPE in the last decades, and presents the existing attempts to improve the wear resistance of this polymer by crosslinking thermal treatments and the incorporation of vitamin $\mathrm{E}$, the use of untreated and functionalized carbon nanostructures, and other hard particle reinforcements. The incorporation of carbon nanostructures and their impact on mechanical properties, wear behavior, and biocompatibility of UHMWPE is thoroughly discussed.

\section{UHMWPE STRUCTURE AND MECHANICAL PROPERTIES}

Ultra-high molecular weight polyethylene is a semi-crystalline high-performance engineering polymer with excellent mechanical and physical properties among thermoplastics (tensile strength, impact strength, abrasion resistance, low creep, low friction coefficient, reduced wear, resistance to fatigue, low permeability, and high corrosion resistance) [1,42]. Table 1 summarizes the physical and mechanical properties of UHMWPE according to molecular weight classification.

Exceptionally long chains of polyethylene form UHMWPE, with each additional molecule improving the whole structure [46]; this gives intrinsic extraordinary physical and mechanical properties tailored to improve UHMWPE clinical performance. Because of the length of its chains and high molecular weight, the processing of this material has proven challenging. Medical grade polyethylene with an average molecular mass of > 2,000,000 a.m.u., molecular weight between 3.5 - 6 million $\mathrm{g} / \mathrm{mole}$, and a degree of polymerization between 71,000 - 214,000 displays a set of ordered regions (extended chain crystalline 10 - $50 \mathrm{~nm}$ thick and 10 - 50 $\mu \mathrm{m}$ long lamellae composed of orthorhombic crystals) embedded in a disordered amorphous phase $[9,45]$. The degree of crystallinity is relevant since higher crystallinity provides a larger elastic modulus, superior yield and fatigue strength, and improved creep resistance [9,8]. High crystallinity degree, associated with the thickness of the lamellar polymer structure, is also responsible for better surface characteristics such as higher hardness, improved wear behavior, lower wear depth, and lower friction coefficient [47]. The amorphous content (e.g., nanometers range) also plays a crucial role in determining UHMWPE physical behavior. Kurtz et al. found that changes (crystallization) in the amorphous regions of the polymer are primarily responsible for the drop in mechanical properties with increasing temperature [45]. In general, acceptable crystallinity ranges of UHMWPE should be between 39 and $75 \%$ for medical-grade applications $[1,48]$. 
N. Camacho, J.M. González Carmona, D.G. Espinosa Arbeláez, G.C. Mondragón-Rodríguez, Stephen W. Stafford

Revista Colombiana de Materiales, ISSN 2256-1013, No 16, pp. 3-28, 2020. https://doi.org/10.17533/udea.rcm.n16a01

Table 1. Physical and mechanical properties of orthopedic grade UHMWPE.

\begin{tabular}{|c|c|c|c|c|c|}
\hline Property & \multicolumn{2}{|c|}{ GUR 1020} & \multicolumn{2}{|c|}{ GUR 1050} & Reference \\
\hline Molecular weight $(\mathrm{g} / \mathrm{mol})$ & \multicolumn{2}{|c|}{$\sim 3.5 \times 10^{6}$} & \multicolumn{2}{|c|}{$5.5-6.0 \times 10^{6}$} & [1] \\
\hline Density $\left(\mathrm{kg} / \mathrm{m}^{3}\right)[43]$ & \multicolumn{2}{|c|}{937} & \multicolumn{2}{|c|}{932} & [44] \\
\hline Charpy impact strength $\left(\mathrm{kJ} / \mathrm{m}^{2}\right)$ & \multicolumn{2}{|c|}{203} & \multicolumn{2}{|c|}{101} & {$[44]$} \\
\hline Mean wear factor $10^{-6}\left(\mathrm{~mm}^{3} / \mathrm{Nm}\right)$ & \multicolumn{2}{|c|}{$3.92 \pm 0.55$} & \multicolumn{2}{|c|}{$3.64 \pm 0.39$} & {$[44]$} \\
\hline \multirow[t]{2}{*}{ Glass transition temperature } & \multicolumn{2}{|c|}{$-150{ }^{\circ} \mathrm{C}$} & \multicolumn{2}{|c|}{$-150^{\circ} \mathrm{C}$} & [9] \\
\hline & Extruded & Molded & Extruded & Molded & \\
\hline Tensile strength at yield (MPa) & $23.6 \pm 0.1$ & $23.6 \pm 0.1$ & $22.3 \pm 0.1$ & $22.5 \pm 0.1$ & [9] \\
\hline Ultimate tensile strength (MPa) & $37.2 \pm 6.4$ & $42.1 \pm 2.7$ & $40.0 \pm 5.0$ & $43.8 \pm 3.5$ & [9] \\
\hline Elongation to failure (\%) & 452 & 440 & 395 & 373 & [45] \\
\hline
\end{tabular}

\section{UHMWPE PERFORMANCE AND ITS CLINICAL CONSEQUENCES}

In 2007, the Canadian Joint Replacement Registry reported that the three main reasons for revisions of primary TKR were osteolysis-induced aseptic loosening, indication present in $33 \%$ of all the cases, UHMWPE wear (30\%), and instability of the implant $(17 \%)$ in 2005 - 2006, demonstrating that degradation of UHMWPE is the principal contributor to the failure of TKRs [9,4]. Furthermore, in 2016, the data obtained from different joint replacement registries across the globe showed that aseptic loosening was still the most common indication for revision surgery, accounting for $29.8 \%$ of all procedures [49]. TKR long-term clinical performance could be described in terms of the number of revision procedures due to the malfunction of the knee implant. In general, the number of revision surgeries is rising in many countries; for instance, Australia reported 3200 revision surgeries for TKR in 2008 , while in 2015 , there were 15,232 revision surgeries [3,50]. In Mexico, the numbers reported by the Secretaría de la
Salud do not seem as significant as in the USA. However, an increase in the number of surgeries performed every year can be observed (Figure 1). Several factors influence the wear of UHMWPE tibial insets [51] (e.g., materials and design, patient height and weight, joint loading during daily activities, patient activity level, and the surgical technique (alignment and soft tissue balancing). Because most of these variables cannot be controlled or measured accurately, scientific community research focuses on developing longer-lasting, more resistant UHMWPE formulations.

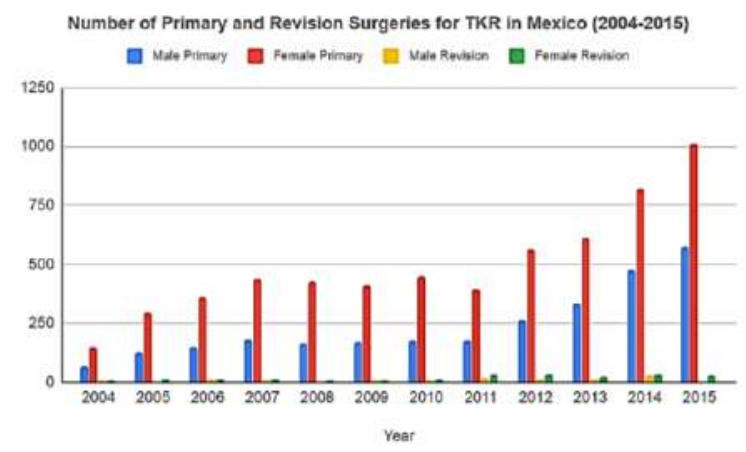

Figure 1. Statistics of TKA performed in Mexico in public institutions from 2004 to 2015. Information obtained from Secretaría de Salud de México. 
Wear, caused by the periodical and combined motions of rolling, sliding, and rotating [52] naturally taking place at the knee joint, results in the UHMWPE tibial insert fatigue. Cyclic deformation of the articulating surface at the microscopic level has been reported to precede wear [9]. Local stresses surpass the yield strength of the articulating surface, resulting in microscopic deformation of the tibial insert and removal of UHMWPE from the tibial insert surface through the abrasive, adhesive, third body, and fatigue wear mechanisms, more specifically from pitting and delamination [15]. The polyethylene insert is the most damaged component because the interactions of the polymer chains are weak compared to those between the metal or ceramic atoms in the femoral knee implant [15]. The most relevant wear patterns at TKR articulating surfaces include burnishing, scratching, pitting, delamination, abrasion, third-body debris wear, and creeping or cold flow $[15,45,52]$. Figure 2 presents five failed UHMWPE components removed after different periods of implantation. All components show damage to the articulating surface regardless of the implantation period. Table 2 provides the information for each component and their Hood score (semi-quantitative wear damage scoring method), which can have a maximum value of 210 points $[15,45,52]$.

The particles of polyethylene produced by the different wear modes (abrasive, adhesive and erosive wear) induce aseptic loosening in an elaborate mechanism involving the formation of reactive tissue. Wear debris varies in size and shape. Figure 3 displays scanning electron microscope photographs showing some of the most common morphologies of wear debris found within knee joint tissue, as presented by Nine et al. [5,53]. Wear debris of different sizes, shapes, and compositions are confined at the bone and joint interface interacting with periprosthetic tissue, influencing the response of periprosthetic cells [5]. The foreign body response evolves into osteoclast bone resorption around the implant and, consequently, osteolysis, which has been documented as the leading cause of implant failure $[4,5,54,55]$.

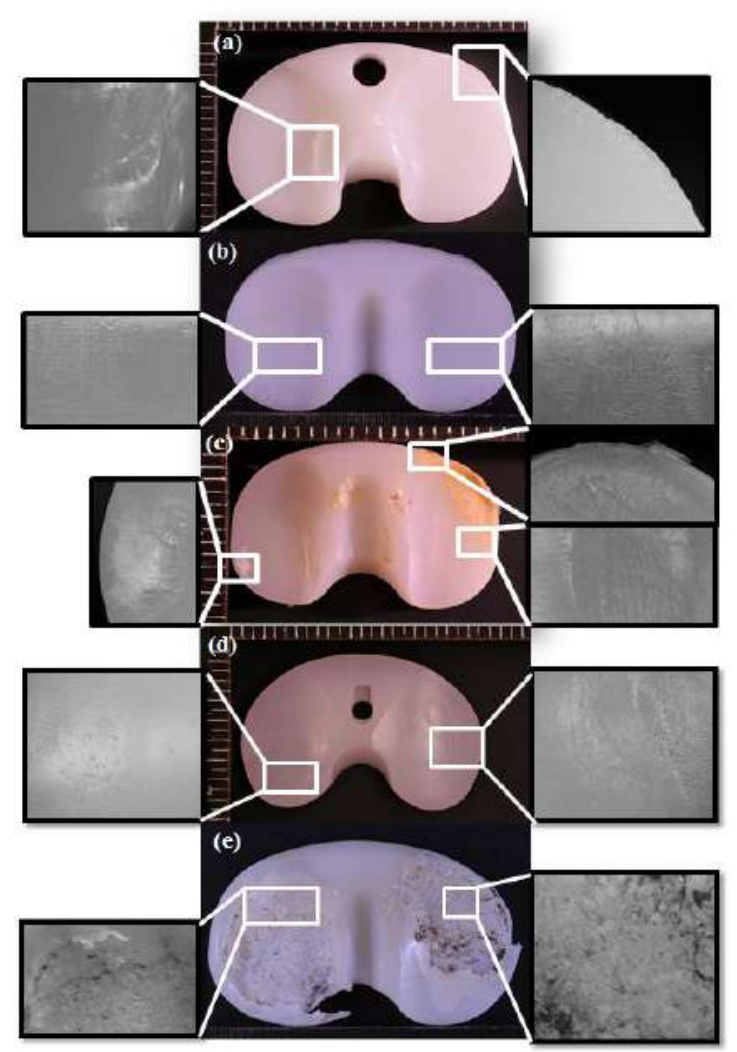

Figure 2. UHMWPE tibial inserts retrieved after a) 5 months, b) 1 year, c) 5 years, d) 7 years, and $\mathrm{e}) 8$ years, all donated by El Paso

Orthopedic Group, El Paso, TX, USA.

The foreign body response, also called a granulomatous response, caused by the presence of wear debris, denotes a nonspecific inflammatory reaction involving activated mononucleated macrophages and fibroblasts phagocytosis. Granulomatous response to UHMWPE particles is size, concentration, and composition-dependent [8]. Particles in the range of 0.3 to $2 \mu \mathrm{m}$ (critical particle size) of wear debris and high doses of critical size particles induce a significant level of secretion of boneresorbing factors $[1,5,45,55]$. 
N. Camacho, J.M. González Carmona, D.G. Espinosa Arbeláez, G.C. Mondragón-Rodríguez, Stephen W. Stafford

Revista Colombiana de Materiales, ISSN 2256-1013, No 16, pp. 3-28, 2020. https://doi.org/10.17533/udea.rcm.n16a01

Table 2. TKR specification and Hood score after implant retrieval.

\begin{tabular}{|c|c|c|c|c|c|}
\hline $\begin{array}{c}\text { Patient } \\
\text { Age \& } \\
\text { Gender }\end{array}$ & $\begin{array}{c}\text { Weight } \\
\text { (Kgs) }\end{array}$ & $\begin{array}{c}\text { Implanted } \\
\text { time (years) }\end{array}$ & Manufacturer & Cause for Removal & $\begin{array}{c}\text { Hood Score } \\
\text { after removal }\end{array}$ \\
\hline $72 / \mathrm{M}$ & 115.5 & $\begin{array}{c}5 \text { months } 12 \\
\text { days }\end{array}$ & Biomet & $\begin{array}{c}\text { Unstable knee with quadriceps } \\
\text { rupture }\end{array}$ & 20 \\
\hline $75 / \mathrm{M}$ & 145 & 1 & Biomet & Unstable knee & 18 \\
\hline $76 / \mathrm{F}$ & 77 & 5 & Biomet & $\begin{array}{c}\text { Left total knee prosthesis } \\
\text { loosening at tibial and femoral } \\
\text { sites }\end{array}$ & 50 \\
\hline $83 / \mathrm{F}$ & NA & 7 & DePuy & $\begin{array}{c}\text { Left total knee loosening with } \\
\text { pain }\end{array}$ & 40 \\
\hline $50 / \mathrm{F}$ & 81.5 & 8 & NA & NA & 119 \\
\hline NA/M & NA & 8 & Biomet & NA & 134 \\
\hline
\end{tabular}

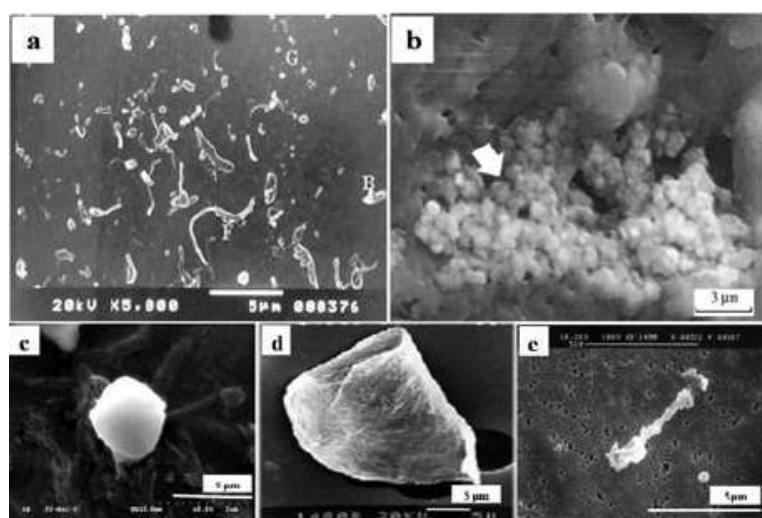

Figure 3. Typical morphologies of wear debris collected from periprosthetic tissue; (a)

UHMWPE, (b) alumina, (c) spherical UHMWPE, $(d)$ sheet/flake type UHMWPE, and (e) UHMWPE fibrils, as presented in Nine et al. [5].

The correlation among bone loss, wear debris, and secreted mediators suggest that the interaction between tumor necrosis factor (TNF- $\alpha$ ) and the receptor activator of nuclear factor kappa-B ligand promotes osteoclast activity, leading to bone resorption and, ultimately, loosening of the implant [5]. Thus, UHMWPE clinical performance is directly related to its mechanical properties, particularly to its wear resistance.

One aspect that has played a crucial role in UHMWPE clinical performance is the sterilization process of these components. High-energy irradiation has been used to sterilize tibial inserts and initiate and increase crosslinking of the polymeric chains, increasing its mechanical properties. However, gamma- and electron beam irradiation in air at a dose level of $25 \mathrm{kGy}$, or higher, produce free radicals, that combined with oxygen lead to long-term postirradiation aging (oxidative degradation) of the material, modifying not only the morphology of the polymer but also its mechanical properties [5,8].

Mechanical properties, including wear resistance of polyethylene, have been demonstrated to decrease because of the oxidative degradation of the material $[8,9,12,13,53]$. The loss of inherent mechanical properties potentially leads to fatigue failure of the articulating surface. An oxidation level of 1.0 to 1.5 is an important threshold for detrimental loss of mechanical properties, so that clinical fatigue may occur [56]. Won, Rohatgi et al. showed a direct correlation between subsurface oxidative degradation and an increased prevalence of delamination in tibial components [57]. It has been observed that when UHMWPE is 
sterilized under gamma and e-beam irradiation, oxidative degradation occurs with increasing in vivo time due to the presence of oxygen in the blood [52]. As explained by Sobieraj and Rinmac, free radicals produced via irradiation react with the oxygen present in UHMWPE producing hydroperoxides. Following hydroperoxide decomposition, free radicals are generated one more time, leading to carbonyl functionalities on the backbone of the polyethylene chains [9]. The process becomes autocatalytic as long as oxygen continues to be present, generating oxidation products such as ketones, alcohols, esters, and carboxylic acids [9]. Long-term post-irradiation aging decreases the molecular weight and embrittles the polymer, leading to a decrease in elongation to failure, ultimate stress, toughness, fatigue crack propagation, decreased $\mathrm{S}-\mathrm{N}$ fatigue life, and an increase in the elastic modulus $[1,24]$, $[25,58]$. These mechanical properties are of great significance when the UHMWPE tibial inserts are subjected to high multiaxial contact stresses that can exceed the yield stress, leading to permanent deformation and finally to the catastrophic rupture and premature failure of the implants. According to the Annual Report 2019 from the American Academy of Orthopedic Surgeons [59], conventional UHMWPE use has decreased in the last years due to the decrease of mechanical properties related to oxidative degradation.

\section{UHMWPE WEAR RESISTANCE IMPROVEMENTS}

Despite the success of UHMWPE as the bearing surface material used in TKRs, concerns regarding implant loosening due to osteolysis started in the 1990s and continue to be one of the main issues of this material. UHMWPE wear particles are the primary cause of osteolysis as they induce an autoimmune response that results in bone resorption. In the last decades, different solutions have been proposed to address degradative oxidation and wear debris production.

Most research focuses on enhancing the wear resistance capacity of the polymer and reducing the oxidation undergone during shelf storage, in vitro, and in vivo caused by the free radicals produced in the sterilization process. One of the paths taken to improve UHMWPE wear resistance has been to increase the molecular weight of the polymer since it is directly related to the toughness of the material $[60,61]$. Other efforts include the use of modified sterilization protocols (still using high-energy radiation to achieve crosslinking of the polymer chains but performed under inert gases or vacuum, reducing oxygen in the sterilization and packaging processes [8]), infusing the polymer with vitamin E, and applying a postirradiation thermal treatment [62].

\subsection{Crosslinking of UHMWPE}

Crosslinked polyethylene (XPE) was developed to improve the wear resistance of the articulating tibial insert and generate longer-lasting knee prosthesis. Oonishi and coworkers, who showed that crosslinking UHMWPE leads to decreased wear, have studied wear resistance of XPE since the 1970s $[9,13,61,68]$. Crosslinking is obtained by high-energy irradiation (over $50 \mathrm{kGy}$ ) because of its capacity to break chemical bonds and produce free radicals in the polymer that react with chain imperfections and other radicals $[9,46,60,63]$. Such reactions result in polymer chains with stable C-C chemical bonds, increasing the molecular mass and the wear resistance of the material [64]. The first generation of XPE was crosslinked at irradiation levels between 50-105 kGy in the 1990s and early 2000s, and when tested in vitro in wear simulators, there was a significant reduction in wear rate when 
N. Camacho, J.M. González Carmona, D.G. Espinosa Arbeláez, G.C. Mondragón-Rodríguez, Stephen W. Stafford

Revista Colombiana de Materiales, ISSN 2256-1013, No 16, pp. 3-28, 2020. https://doi.org/10.17533/udea.rcm.n16a01

compared to conventional UHMWPE [9, $45,46,61]$.

Nonetheless, it was also noticed that gamma irradiation in air produced free radicals in the polymer, causing oxidative degradation of the polymer, decreasing the intrinsic mechanical properties of UHMWPE [1,64,65]. The second generation, known as highly crosslinked polyethylene (HXLPE), was developed in the 2000s. HXLPE has a proven capability both in vitro and in vivo to reduce polyethylene wear [21]. Several good early clinical results have been reported for knee replacement fabricated with highly crosslinked polyethylene (HXLPE), and according to the Annual Report of 2018 of the American Academy of Orthopedic Surgeons, HXLPE was used in primary and revision surgeries performed from 2012 to 2017 in at least $35 \%$ of all registered procedures [59]. Depending on the amount of crosslinking required, doses between 75 and 100kGy are typically used, with crosslinking density increasing with higher dosages [21]. Free radicals, however, are also produced in the crystalline phase of the material, and these free radicals are unable to react with other polymeric chains. Those remaining free radicals may react in vivo with oxygen in the body, and degradative oxidation can still occur.

Thermal treatments such as annealing and remelting are employed after crosslinking methods to minimize degradative oxidation, reducing unreacted free radicals. However, thermal treatments seem to reduce the mechanical properties of HXLPE [8,59]. Annealing occurs below the melting temperature of the material, while re-melting takes place above the melt transition temperature. The re-melting process involves the dissolution and reformation of crystalline regions, minimizing the possibility of residual free radicals. Both thermal treatments are conducted at ambient pressure
[8,9,59]. Even though HXLPE has successfully reduced wear rates, achieving an acceptable laboratory and clinical performance, one of the drawbacks is the tradeoff of other mechanical properties such as ultimate stress and strain, which showed reduced values compared to conventional UHMWPE $[9,66]$. Furthermore, crosslinking decreases fatigue crack propagation resistance and Charpy impact toughness [9] and fracture toughness as determined by Izod impact toughness [66]. The higher the irradiation dose, the lower the fracture toughness is.

Different methods have been employed to retain the mechanical properties of conventional UHMWPE and the enhanced wear resistance offered by highly crosslinked polyethylene, given the necessity for improved fracture resistance. Sequential annealing, mechanical deformation, and high-pressure crystallization after melting and incorporating vitamin-E are only a few of the research efforts performed in the last few years that have been analyzed in a clinical setting [13].

Sequential irradiation and annealing have been introduced to effectively reduce free radicals in the polymer without re-melting the material without the adverse changes to crystallinity [9]. The material is first irradiated at a low dose (under $30 \mathrm{kGy}$ ) and then annealed for a given period; the process is repeated three times for a total irradiation dose of $90 \mathrm{kGy}$ so that fewer residual free radicals are produced after each irradiation cycle, and annealing will be more effective extinguishing these free radicals [9,67-71]. Stryker Orthopedics, Mahwah, NJ, who currently has sequentially irradiated annealed UHMWPE on the market, claimed that this process produces a highly crosslinked oxidatively stable UHMWPE [9]. On the other hand, Biomet, Warsaw, IN, has developed an anisotropic highly crosslinked 
polyethylene using mechanical deformation to enhance mechanical properties; ArCom $\mathrm{XL}$ is prepared in four steps, gammairradiation of isostatically molded rods, preheating below melting transition temperature (Tm), ram extrusion through a circular die with a compression ratio of 1.5 , and annealing below Tm to relief residual stresses [9]. This local manufacturer stated that ArCom XL displays better wear resistance than conventional UHMWPE from Biomet and excellent oxidative stability in an accelerated aging study [9,72]. However, gammasterilized UHMWPE and annealed crosslinked polyethylene have been shown to oxidize in vivo, presumably because of free radical remaining in the polymer [56].

High pressure and high-temperature processing is another approach under investigation to increase the mechanical properties of XPE [9]. It has been noted that the process results in an increase in crystallinity and in the size of crystalline lamellar characterized by large crystalline regions with hexagonal lattice structure formed at elevated temperature and pressure and upon cooling and return to ambient pressure, the crystals revert to an orthorhombic structure [67,71]. The higher degree of crystallinity, the better fatigue crack propagation resistance.

\subsection{Vitamin-E-stabilization}

Antioxidant vitamin E ( $\alpha$-tocopherol) has been introduced for tibial inserts to prevent crosslinked and non-crosslinked UHMWPE oxidation. Vitamin-E can consume free radicals in the crystalline and amorphous phases, mitigating the effects of degradative oxidation and the reduction of UHMWPE elongation at break, tensile strength, fracture toughness, and fatigue crack propagation resistance $[8,9,23,73]$. Two methods for incorporating vitamin-E have been reported in the literature, the first one is to combine
vitamin-E with UHMWPE powder before consolidation (Zimmer Vivacit-E®), and the other is to allow diffusion of vitamin-E into bulk UHMWPE (Biomet E1®) [23,25,74].

The first method incorporates vitamin $\mathrm{E}$ as a liquid antioxidant into UHMWPE powder before the consolidation and irradiation of the material [75]. HXLPE blended with vitamin $\mathrm{E}$ (VitE poly) has also shown slightly inferior wear properties when compared with HXLPE without vitamin-E; generally, VitE poly has been shown to decrease crosslink density (resulting in increasing wear) with increasing concentration in blended vitamin-E materials to the point that concentrations above $0.3 \mathrm{wt}$. $\%$ cannot achieve high crosslinking levels, even at a gamma dose of $200 \mathrm{kGy}[25,76]$. On the other hand, diffusion of vitamin-E after crosslinking is performed by doping UHMWPE with vitamin-E and then homogenizing vitamin-E content into an inert atmosphere [23]. Homogenizing vitamin-E content is necessary since an adequate antioxidant concentration throughout the implant can be achieved in this step. The drawback of this method is the oxidation that can occur after crosslinking and before the diffusion of vitamin-E [1,23].

In terms of decreasing or eliminating oxidative degradation of UHMWPE, the incorporation of vitamin $\mathrm{E}$ has shown promising results. Retrieved infused vitaminE polyethylene did not show an increase in the oxidation index in the study performed by Tone et al. while conventional e-beam sterilized UHMWPE, conventional gamma sterilized polyethylene and highly crosslinked polyethylene showed high values of oxidation index [56]. Moreover, antioxidant vitamin-E doping of UHMWPE has shown excellent wear resistance, increased elongation to break, better toughness, and superior oxidative stability than XPE $[9,77]$. In terms of tribological properties, vitamin-E stabilized UHMWPE 
has also shown positive results. Wear tests in clean serum and serum with third-body particles resulted in a 4-fold to 10-fold decrease in wear rates compared to conventional UHMWPE [1,78]. Results indicated that the addition of vitamin-E could prevent delamination caused by oxidation and fatigue, and in consequence, increase the service life of UHMWPE knee liners, which explains its usage rate steady increase from $2.5 \%$ in 2012 to over $25 \%$ by 2018 in primary surgeries and from 0.6 to $8 \%$ in revision surgeries over the same period [59].

\subsection{Summary}

Since the appearance of UHMWPE in the total knee replacements, the wear resistance and mechanical properties of the polymer have been improved through several methods to prevent premature failure of the prosthesis. Table 3 displays the methods employed throughout the years and their results.

\section{UHMWPE COMPOSITES}

AND

ITS

A composite material combines two or more materials that result in better properties than those of the individual components. It is important to develop UHMWPE-based composites with low friction coefficients and high wear resistance while other desirable properties are not sacrificed. The incorporation of different reinforcement materials has been explored to meet high demands for enhanced tribological performance and improved UHMWPE mechanical properties [10,38,46,60,79,80]. Research groups have incorporated a variety of reinforcements such as carbonaceous particles [10-12,31,32,35,39,60,63,81], titanium dioxide [82,87], kaolin [83,84], zinc oxide $(\mathrm{ZnO})$ [26], hydroxyapatite (HA) [85], zeolite [27], platinum-zirconium (Pt-Zr) crystal particles [86], zirconium particles [28,86], and alumina $\left(\mathrm{Al}_{2} \mathrm{O}_{3}\right)$ [87] or a combination of different particles [87-89] to improve wear resistance of UHMWPE; in orthopedics, UHMWPE composites are developed as an alternative to highly crosslinked polyethylene.

The incorporation of nanofillers has proven to be an effective method for further improving UHMWPE wear resistance when the appropriate particle and concentration are selected, and a uniform distribution is achieved. However, UHMWPE exceptionally high viscosity and its non-polar nature prevent the application of conventional techniques to produce UHMWPE-based composites [60]. Moreover, new UHMWPEbased composites must not sacrifice conventional UHMWPE excellent attributes such as biocompatibility and chemical stability.

\subsection{UHMWPE and untreated carbon nanotubes}

The unique mechanical properties of carbon nanotubes (CNTs) have motivated scientists and engineers to exploit their application in advanced composite materials, principally in polymer composites, to improve their performance [34,90]. CNTs are extremely strong and stiff 1D carbonaceous materials, with Young's modulus in the TPa range, yet outstandingly flexible with break strains over $5 \%$ [34], making them an excellent candidate filler in ductile nanocomposites [12]. Effective utilization of CNTs in composite applications strongly depends on the homogeneous dispersion throughout the matrix and maintaining the integrity of CNTs $[12,34]$. 
N. Camacho, J.M. González Carmona, D.G. Espinosa Arbeláez, G.C. Mondragón-Rodríguez, Stephen W. Stafford Revista Colombiana de Materiales, ISSN 2256-1013, No 16, pp. 3-28, 2020. https://doi.org/10.17533/udea.rcm.n16a01

Table 3. Wear improvement of UHMWPE.

\begin{tabular}{|c|c|c|c|}
\hline Employed method & Positive results & Negative results & Reference \\
\hline Blendig with carbon fibers & $\begin{array}{c}\uparrow \text { Hardness } \\
\uparrow \text { Creep resistance }\end{array}$ & $\begin{array}{c}\text { Failure modes of matrix-filler } \\
\text { interface }\end{array}$ & [8] \\
\hline $\begin{array}{c}\text { High irradiation dose (50- } \\
105 \mathrm{kGys}) \\
\text { XPE }\end{array}$ & $\begin{array}{c}\uparrow \text { Polymer crosslinking } \\
\uparrow \text { Molecular mass } \\
\downarrow \text { Wear rate }\end{array}$ & $\begin{array}{c}\downarrow \text { Mechanical properties (ultimate } \\
\text { strength and strain) } \\
\downarrow \text { Oxidation stability } \\
\uparrow \text { Free radicals } \\
\end{array}$ & $\begin{array}{l}{[9,13,19,20,} \\
21,61,68]\end{array}$ \\
\hline $\begin{array}{c}\text { Highly crosslinking } \\
\text { (75-100 kGys) } \\
\text { HXLPE }\end{array}$ & $\downarrow$ Wear rate & $\begin{array}{c}\downarrow \text { Mechanical properties (ultimate } \\
\text { strength and strain) } \\
\downarrow \text { Oxidation stability } \\
\uparrow \text { Free radicals }\end{array}$ & [21] \\
\hline $\begin{array}{l}\text { Highly crosslinking + } \\
\text { Annealing }\end{array}$ & $\begin{array}{c}\downarrow \text { Free radicals } \\
\uparrow \text { Oxidation stability } \\
\downarrow \text { Wear rate }\end{array}$ & $\begin{array}{c}\downarrow \text { Mechanical properties (ultimate } \\
\text { strength and strain) } \\
\downarrow \text { Fatigue crack propagation resistance } \\
\downarrow \text { Impact toughness }\end{array}$ & {$[8,59]$} \\
\hline $\begin{array}{c}\text { Highly crosslinking + } \\
\text { Remelting }\end{array}$ & $\begin{array}{c}\downarrow \text { Free radicals } \\
\uparrow \text { Oxidation stability }\end{array}$ & $\begin{array}{c}\downarrow \text { Mechanical properties (ultimate } \\
\text { strength and strain) }\end{array}$ & {$[8,9,59]$} \\
\hline $\begin{array}{c}\text { Highly crosslinking } \\
\text { (sequential irradiation) }+ \\
\text { Annealing }\end{array}$ & $\begin{array}{l}\downarrow \text { Free radicals } \\
=\text { Crystallinity }\end{array}$ & $\begin{array}{l}\text { Free radicals remained in the material } \\
\text { resulting in oxidation }\end{array}$ & [9] \\
\hline $\begin{array}{c}\text { Highly crosslinking }+ \\
\text { Mechanical deformation }+ \\
\text { Annealing }\end{array}$ & $\uparrow$ Oxidation stability & $\begin{array}{l}\text { Free radicals remained in the material } \\
\text { resulting in oxidation }\end{array}$ & [9] \\
\hline $\begin{array}{l}\text { Incorporation of vitamin } \mathrm{E} \\
\text { (doping or diffusion) }\end{array}$ & १Oxidation stability & $\begin{array}{c}\downarrow \text { Wear resistance } \\
\downarrow \text { Crosslinking }\end{array}$ & $\begin{array}{c}{[8,9,21,23-} \\
25,73,74]\end{array}$ \\
\hline $\begin{array}{l}\text { Highly crosslinking + } \\
\text { Vitamin E }\end{array}$ & $\begin{array}{c}\uparrow \text { Oxidation stability } \\
\uparrow \text { Wear resistance } \\
\uparrow \text { Mechanical properties } \\
\text { (toughness, elongation at break) } \\
\uparrow \text { Oxidation stability } \\
\end{array}$ & $\begin{array}{l}\text { Oxidation of the material remained } \\
\text { an issue }\end{array}$ & [9] \\
\hline $\begin{array}{l}\text { Processing at high } \\
\text { pressure and high } \\
\text { temperature }\end{array}$ & $\begin{array}{c}\uparrow \text { Fatigue crack propagation } \\
\text { resistance } \\
\uparrow \text { Crystalinity } \\
\uparrow M e c h a n i c a l \text { properties } \\
\text { (toughness, elongation at break) }\end{array}$ & NA & [9] \\
\hline
\end{tabular}

Different techniques have been used to prepare bulk material, films, and fibers of UHMWPE-CNT composites, including solution or dry dispersion of CNTs, solution casting, electrostatic spraying, and gel spinning [91]. However, the results show the formation of a segregated structure with small agglomerations and entanglement of CNT inside the polymeric matrix $[31,91,92]$. CNTs are inclined to cover the UHMWPE powder surface (as displayed in Figure 4a), resulting in a CNT network formation throughout the polymer (Figure $4 b$ ).

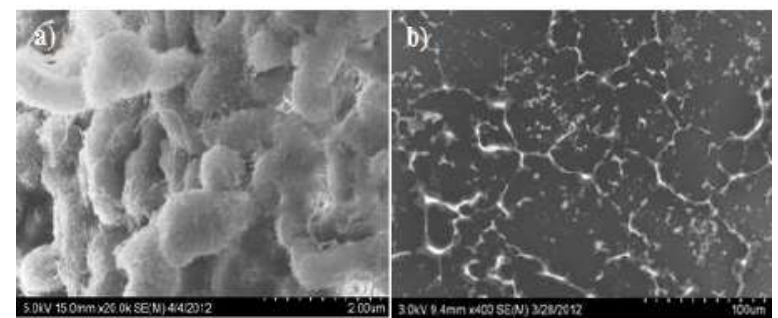

Figure 4.MWCNTs @ 1.25 wt.\% (a) covering UHMWPE powder surface and (b)UHMWPE$M W C N T$ showing a segregated structure on the composite surface.

Regardless of this drawback, some outstanding results have been achieved [36,93]; for instance, Ruan et al. enhanced the toughness of UHMWPE films through the 
addition of only 1 wt. \% of multiwalled carbon nanotubes (MWCNTs), leading to a $150 \%$ increase in strain energy density, $\sim 140$ $\%$ increase in ductility, and up to $25 \%$ in strength [34]. Even though some agglomerations existed after solution casting, the entangled MWCNTs showed a similar role to taut-tie molecules, which act as a loadbearing center in the gel-spun fibers. Meanwhile, Xue et al. tested creep and wear resistance of UHMWPE-HDPE, incorporating from 0.2 to 2 wt. $\%$ carbon nanotubes, resulting in improved mechanical properties of the composite compared to pure UHMWPE [12]. The highest yield stress with a value of $29.9 \mathrm{MPa}$ was achieved with a mixture of $80 \%$ UHMWPE, $20 \%$ HDPE, and 2 wt. \% of untreated CNTs, while the combination of $80 \%$ UHMWPE, $20 \%$ HDPE, and 2 wt. \% of $\mathrm{HNO}_{3}$-treated CNTs displayed the highest tensile strength. In terms of wear resistance, the addition of CNTs significantly reduced the polymer wear rate (Figure 5); the wear rate decreased as the CNT content was increased. Wear resistance improvements correlate with an increase of the E modulus; the addition of only $0.25 \mathrm{wt}$. $\%$ CNTs into the polymer blend reduced the wear rates by $\sim 50 \%$. Similarly, Fonseca et al. observed an enhancement of $80 \%$ in UHMWPE Young's modulus and a $38 \%$ increase in toughness for 1 wt. \% CNT concentration blended by the ball milling method and achieving a relatively uniform distribution of the filler [32].

Figure 6, as presented by Xue et al. [12], displays the wear marks after sliding against XCrNi10-18 on (a) UHMWPE, UHMWPE/HDPE, and (c) composite with 80
$\%$ UHMWPE, $20 \%$ HDPE, and 2 wt. \% of untreated CNTs. The formation of chips on the wear mark exit is visible in all three samples. Longer chips are observed for the combination of UHMWPE/HDPE and UHMWPE/HDPE/CNT, suggesting that the addition of HDPE allows for the mechanical drawing of the material without much resistance. The scratches, parallel to the sliding direction, indicate abrasive wear damage in all three samples. However, wider and deeper scratches are observed for UHMWPE/HDPE/CNT, suggesting a potential detrimental effect of CNTs on the wear of the polymer when the debris is produced, and the polymer has shorter chains and a lesser number of entanglements (due to the presence of HDPE in this case). Composites with 2 wt. \% CNTs presented major fatigue wear, and larger wear debris particles were detached from the surface, causing deeper scratches parallel to the sliding direction [12].

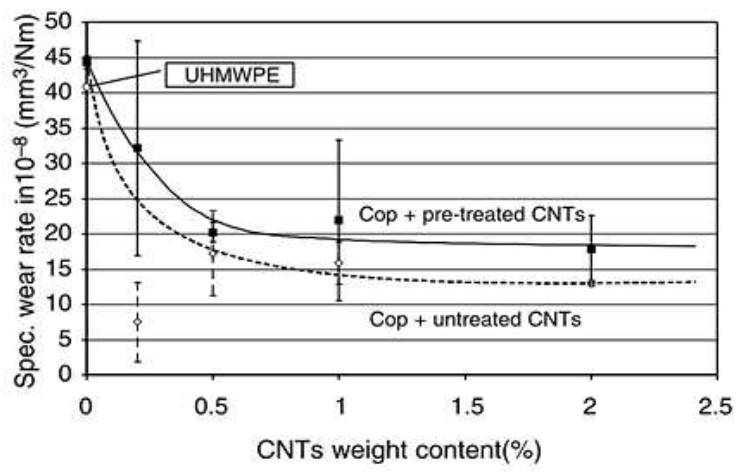

Figure 5. Steady wear rate of UHMWPE, $80 \mathrm{wt}$. $\%$ UHMWPE-20 wt. \% HDPE- nitric acid pretreated CNT and $80 \mathrm{wt}$. \% UHMWPE-20 wt. \% HDPE-untreated CNT as presented by Xue et al.[12]. 


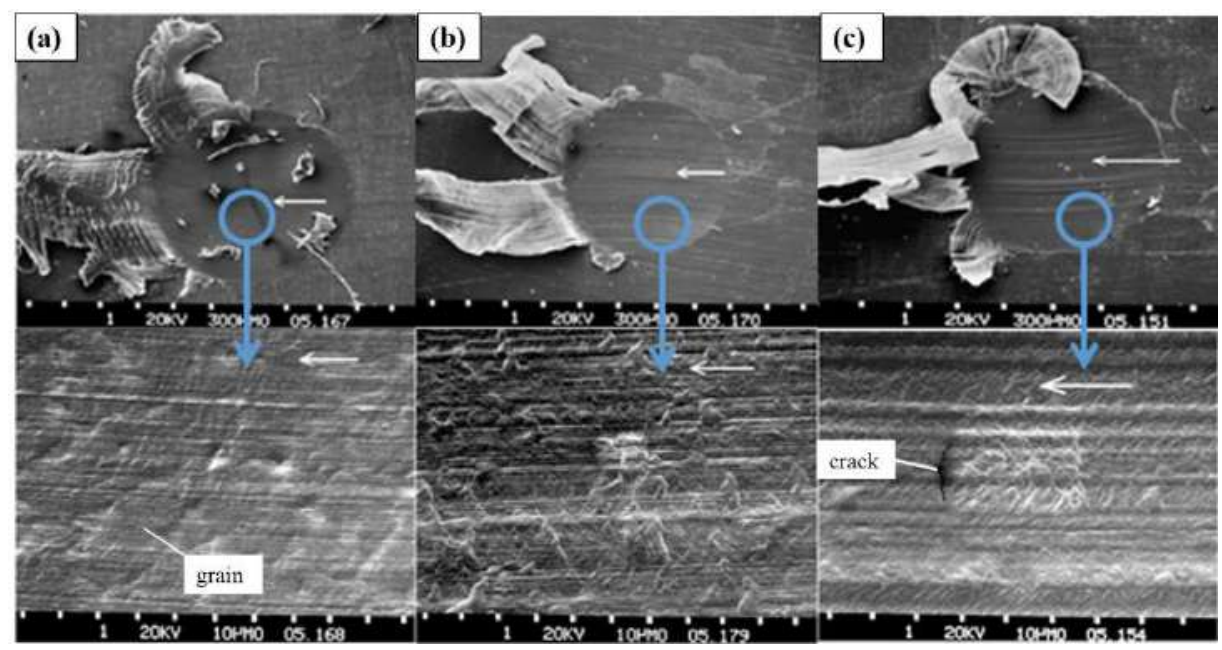

Figure 6. Micrographs of worn surfaces of (a) UHMWPE, (b) 80 wt. \% UHMWPE-20 wt. \% HDPE, (c) 80 wt. \% UHMWPE-20 wt. \% HDPE-2 wt. \% CNTs with the arrows showing sliding direction, adapted from [12].

On the other hand, Camacho et al. [92] incorporated 1.25 wt. \% of MWCNTs in conventional medical-grade UHMWPE by solution blending. The samples were manufactured at 24.1 MPa and irradiated with $25 \mathrm{kGys}$. The samples were tested for two million cycles under dry conditions, resulting in a reduction of $86.7 \%$ in material loss and a significant reduction of wear mark depth. Likewise, Golchin et al. [88] found that the addition of 0.5 wt. \% MWCNT/graphene oxide decreased the friction and wear rate of UHMWPE. Generally, it seems that the influence on wear resistance of carbon nanostructures in UHMWPE is positive with wear factor, wear loss, or depth wear reductions between 20 and $80 \%$ compared to pure UHMWPE [34,94,95].

Results have varied depending on CNT concentrations and dispersion techniques, modifying the wear and fracture mechanisms of the matrix [93-95]. Nevertheless, all the studies performed have resulted in a valuable increase in wear resistance, enhanced surface hardness, restricted plastic displacement, and better mechanical behavior when reinforced with these nanoparticles [96].
Another advantage of CNTs is a strong radical reduction after gamma irradiation in air $[11,63]$. It is known that $\gamma$-irradiation produces free radicals that result in oxidation of the UHMWPE tibial component, which decreases the mechanical properties of the polymer. The addition of MWCNTs increases the oxidative stability of the nanocomposite, as hypothesized by Camacho et al. [92], and shown by Martínez-Morales et al.[11,63], inhibiting some of the effects of $\gamma$-radiation. These findings indicate that MWCNTs could become a promising antioxidant alternative from a chemical stability perspective $[15,70$, 94].

UHMWPE-CNT composites seem to induce a similar biological response from the biocompatibility point of view than conventional UHMWPE. Suñer et al. studied the specific biological activities of UHMWPE-MWCNTs wear debris, concluding that the nanocomposite reduced osteolytic potential compared to UHMWPE. No adverse effect was found on L929 fibroblast cell viability on any of the concentrations tested [45]. Similarly, Camacho et al. [97] analyzed the cytotoxicity 
and proinflammatory mediator production in murine macrophage-like Raw 264 cells. The cytotoxicity of UHMWPE debris was comparable to that of conventional UHMWPE. Furthermore, it was found that UHMWPE-CNT debris did not induce interleukin 6 (IL-6) production after $168 \mathrm{~h}$ of exposure (Figure 7), showing a better response than conventional UHMWPE debris. Even though the study showed an increase in tumor necrosis factor $\alpha(\mathrm{TNF}-\alpha)$ production in the presence of UHMWPECNT debris, the increased production was not significant.

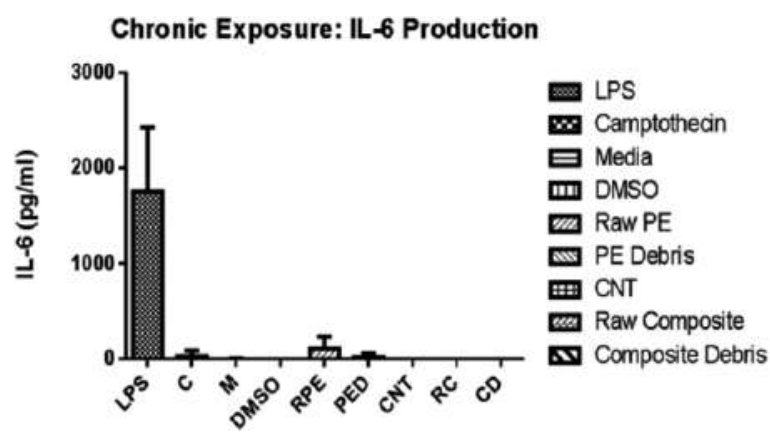

Figure 7. IL-6 production in murine macrophage-like Raw 264 cells after 168 h of exposure to UHMWPE and UHMWPE-MWCNT composite [97].

\subsection{UHMWPE and functionalized carbon nanotubes}

Good interfacial bonding is required to achieve load transfer across the CNT-matrix interface for the mechanical properties of the nanocomposite to be improved [31,34,98], which is the main reason to improve particle dispersion and the strength of the filler-matrix interface. Chemical functionalization is the most widely used method to make CNT compatible with the hydrophobic nature and low polarity of UHMWPE [34,98]. CNT chemical functionalization is achieved through covalent linkage, non-covalent supramolecular absorption, defect functionalization, and click chemistry modification [31,99]. Functionalization with nitric and sulfuric acids has been used repeatedly by different groups [35], resulting in better dispersion of CNTs in the polymeric matrix than pristine CNTs. For instance, Rama and Kanagaraj results showed a $44 \%$ increase in yield strength, $70 \%$ in fracture strain, and $176 \%$ in toughness with the incorporation of only 2 wt. \% carbon nanotubes previously treated with nitric and sulfuric acid [81]. The treated MWCNTs contained carboxyl, carbonyl, and hydroxyl groups.

Other chemicals have also shown promising results; Zoo et al. evaluated the material loss and friction coefficient of UHMWPE when incorporating carbon nanotubes with concentrations up to 0.5 wt. \% using toluene to provide a more active blending between matrix and filler. Even though material loss significantly decreased, it was observed that the friction coefficient increased slightly [37]. Moreover, UHMWPE worn specimens displayed a smoother surface with broader and deeper tracks than those found for the nanocomposite, which showed locally smashed regions [37]. Maksimkin et al. incorporated fluorinated MWCNTs by ball milling followed by hot pressing resulting in tensile strength increase by a factor of 6.3 when compared to neat UHMWPE [100]. Samad et al. proved that on 0.2 wt. \% of plasma-treated CNTs increased the number of cycles without fail by $300 \%$ compared to neat UHMWPE; these results are comparable to the results obtained with highly XPE, and these values represent the highest enhancement seen for these composite materials [101]. These findings indicated that using CNTs as reinforcement particles contributes to a change in UHMWPE wear mechanisms, especially when these are functionalized and act as nucleation agents inside the polymer matrix [37,100]. Dintcheva et al.[31] employed hindered amine light stabilizers covalently linked to the outer surface of MWCNTs; nonetheless, 
the morphological analysis still exposed a segregated structure like the one previously displayed in Figure 4. Other efforts led by Dintcheva include the use of polyhedral oligomeric silsesquioxane and alphatocopherol (vitamin-E) to increase the interfacial bonding between carbon nanotubes and UHMWPE [98,102]. Meanwhile, Amoli et al. produced UHMWPE-MWCNT composites with hydroxyl functionalized MWCNTs varying in concentration from $0.5-3.5 \mathrm{wt}$. \% prepared via in situ polymerization; crystal content increased with increasing concentrations of MWCNTs up to $1.5 \mathrm{wt}$ \% [90]. As mentioned in previous sections, the higher the degree of crystallinity, the larger modulus of elasticity, leading to superior yield and fatigue strength and improved resistance to creep deformation [9].

Chemical treatments combined with gamma irradiation have been studied as well. Sreekanth P.S.R. and S. Kanagaraj explored traditional chemical functionalization through sulfuric and nitric acid prior sterilizing their samples by $100 \mathrm{kG} \gamma$ irradiation; results presented in their study showed a uniform distribution of the filler with an increase in surface hardness of $89 \%$ and $73 \%$ reduction in wear volume with the incorporation of 2 wt. \% MWCNTs [35].

\subsection{UHMWPE and other carbon nanostructures.}

Other carbon nanostructures such as graphene and graphite nanoplatelets have been explored in more recent studies [39,41,88]. Graphene is a thick monolayer displaying carbon atoms arranged in a 2D honeycomb structure, while graphite nanoplatelets consist of small stacks of graphene 1 to 15 nanometers thick. The typical filler in UHMWPE nanocomposites are bilayer graphene, graphene nanoplatelets, and graphene oxide; one advantage of these $2 \mathrm{D}$ structures over CNTs is their large interface that results in more effective load transfer between the matrix and the nanostructures [91]. Liu et al. modified graphite platelets with an organosilane to effectively disperse the particle in UHMWPE and improve the matrix-filler interface. The incorporation of 0.5 wt. \% surface-modified graphite platelets resulted in an improvement of wear resistance of $980 \%$ [60]. The reduction in wear and friction can be attributed to the layered structure of the graphite nanoplatelets, which displayed better dispersing behavior than CNTs [10]. Oppositely, D. Lahiri et al. showed that the wear resistance of UHMWPE reinforced with graphene platelets decreased as the concentration of graphene increased; however the friction coefficient was efficiently reduced in concentrations ranging from 0.1 to 1 wt. \% [39]. The reduction of wear resistance with higher particle concentration could be attributed to the poor reinforcement dispersion in the matrix, where a granular segregated structure forms in the nanocomposite surface [40].

\subsection{UHMWPE and hard particles.}

Many different types of fillers have been used to improve the wear performance of UHMWPE; among these are talc [10], halloysite nanotubes [103], zeolite [27], hydroxyapatite particles (HAp) [104,29,30], nano- $\mathrm{TiO}_{2} \quad[82,104]$, platinum-zirconium quasicrystals [86], zirconium particles [28], zinc oxide [26,28], kaolin [84], and boroncarbide [105]. In more recent years, solid lubricants such as molybdenum disulfide $\left(\mathrm{MoS}_{2}\right)$ have also been employed as hard particle fillers to improve UHMWPE tribological characteristics [10]. Nevertheless, the complex processing procedure makes these additives extremely costly [10]; because of this, silicate minerals have been studied for the same purpose. In their work, Chang et al.[10] introduced talc particles, solid lubricating agents, in 
UHMWPE at concentrations of 10 and 20 wt.\%. It was found that the incorporation of talc particles reduced the presence of wear tracks and that the reduction in wear damage is dependent on the properties of both the talc filler and the UHMWPE.

Hydroxyapatite is a bioactive ceramic that can be found in mineral bone. Its mechanical properties had made this material suitable for reinforcing polymeric matrices $[10,85]$. The average particle size of HA is in the order of microns. However, more recent studies have obtained synthetic HA particles in the nanoscale. These have been successfully incorporated in UHMWPE by Fang et al. [29, $30,104]$, at a concentration of 20 wt. $\%$ by wet ball milling and swelling techniques to achieve a homogeneous distribution of the particles after compression and injection molding. The nanocomposite displayed an elastic modulus of $7 \mathrm{GPa}$ and elongation to failure of $375 \%$; this large deformation mechanical behavior was attributed to the fine dispersion of the nanoparticles in the UHMWPE matrix. Other studies focused on tribological properties, exploring concentrations of HAp ranging from 0.1 wt. $\%$ to $7 \%$ and obtaining reduced friction coefficients and wear rates when compared to conventional UHMWPE, especially after gamma and nitrogen ion beam irradiation
[106] . Nevertheless, it has been concluded that the full potential of UHMWPE-HAp composites in terms of mechanical properties will not be achieved unless coupling agents are used to increase the interfacial bonding between matrix and reinforcement [106].

Finally, recent literature has shown the incorporation of different fillers and surface modification. Y. Liu and S. Sinha [89] incorporated nacre and CNT fillers to UHMWPE powder and coated the bulk material with perfluoropolyether (PFPE) before studying wear mechanisms on a pinon-disk tribometer. It was observed that the surface treatment decreased the wear resistance of the material under wet conditions by PFPE, forming hydrogen bonds with water and decreasing the effect of the lubricant.

\subsection{Summary of nanoparticle incorporation in UHMWPE}

In recent year, a several nanoparticles have been used to improve the wear resistance and oxidation stability of UHMWPE. The success of nanoparticle reinforcement is dependant on the nature of the nanoparticles, its concentration, and its distribution throughout the matrix. Table 4 displays the nanoparticles employed in recent years and their results.

Table 4. UHMWPE composites and tailored properties.

\begin{tabular}{|c|c|c|}
\hline System(s) & Improvements & Reference \\
\hline $\begin{array}{l}1 \text { wt. \% CNTs - Ultrasonic vibration in } \\
\text { xylene }\end{array}$ & $\begin{array}{l}\uparrow \text { Toughness, } 150 \% \varepsilon \text { energy } \rho, 140 \% \text { ductility, } 25 \% \\
\text { strength }\end{array}$ & [34] \\
\hline $0.2-2$ wt. $\%$ Solution blending & $\begin{array}{l}\uparrow \text { Mechanical props, tensile strength, yield } \sigma, \text { E- } \\
\text { module } \\
\downarrow \text { Wear-rate }\end{array}$ & [12] \\
\hline 1 wt. $\%$ ball milling & $\uparrow 38 \%$ toughness, $80 \%$ E-module & [32] \\
\hline $1.25 \%$ wt. Solution blending & $\begin{array}{l}\downarrow 86.7 \% \text { material loss, oxidation } \\
\uparrow \text { Hardness, creep deformation }\end{array}$ & [92] \\
\hline Graphene oxide MWCNTs 0.5 wt. \% & $\downarrow$ CoF, Wear-rate & [88] \\
\hline $\begin{array}{l}\text { CNTs functionalized } 2 \text { wt. \% nitric }+ \\
\text { sulfuric acid }\end{array}$ & $\begin{array}{l}\uparrow 44 \% \text { yield strength, } 70 \% \text { fracture strain, } 176 \% \\
\text { toughness }\end{array}$ & [81] \\
\hline CNTs - Toluene, 0.5 wt. $\%$ & $\begin{array}{l}\uparrow \text { CoF } \\
\downarrow \text { Wear material loss }\end{array}$ & [37] \\
\hline
\end{tabular}


N. Camacho, J.M. González Carmona, D.G. Espinosa Arbeláez, G.C. Mondragón-Rodríguez, Stephen W. Stafford Revista Colombiana de Materiales, ISSN 2256-1013, No 16, pp. 3-28, 2020. https://doi.org/10.17533/udea.rcm.n16a01

\begin{tabular}{|l|l|c|}
\hline $\begin{array}{l}\text { Fluorinated MWCNTs, ball milling, } \\
0.1-1 \text { wt. \% }\end{array}$ & $\uparrow 630 \%$ tensile strength & {$[100]$} \\
\hline Plasma treated 0.2 wt. \% CNTs & $\uparrow$ No of cycles without failing by 300\% $\%$, & {$[101]$} \\
\hline $0.5-3.5$ hydroxyl functionalized & $\begin{array}{l}\uparrow \text { Crystallinity, E-module, yield \& fatigue strength, } \\
\text { creep deformation }\end{array}$ & {$[90]$} \\
MWCNTs & $\begin{array}{l}\downarrow 73 \% \text { wear volume } \\
\uparrow 89 \% \text { hardness }\end{array}$ & {$[35]$} \\
\hline $\begin{array}{l}\text { Functionalized sulfuric }- \text { nitric acid }+ \\
100 \text { KGys, } 2 \text { wt. \% }\end{array}$ & $\uparrow 980 \%$ wear resistance & {$[91]$} \\
\hline Organosilane modified CNTs & $\downarrow$ Wear tracks presence & {$[10]$} \\
\hline Talc particles & $\downarrow$ CoF, Wear-rate & {$[106]$} \\
\hline Hydroxyapatite & \\
\hline
\end{tabular}

\section{CONCLUSIONS}

The development and advance in the production and tailoring of UHMWPE mechanical properties have allowed the replacement of diseased or traumatized knee joints, alleviating pain and allowing patients to return to usual daily activities for the last five decades. With the number of people receiving total knee replacements growing and an overall increase in lifespan, the need for a longer-lasting total knee replacement is becoming more urgent. UHMWPE is a complex material, and its physical and mechanical properties are dependent on functional loading and environmental conditions. It is essential to fully understand the material and mechanical properties for individual formulations of UHMWPE and its composites. UHMWPE is perceived as a clinically successful material in total joint implants, however, the UHMWPE must continue to be improved, especially with the rising patient demands. Wear debris-induced osteolysis continues to affect the performance and life span of total knee replacements. Despite the improvements documented by several research groups such as crosslinking, antioxidant incorporation, and the addition of different fillers, there is still a pressing need to improve the material. Moreover, there is no information on UHMWPE-based composites being used at the clinical level when it comes to the new blends with carbonaceous materials and ceramic particles. It is of great interest to the orthopedic community to see how these materials will perform clinically and continue enhancing the tribological performance of UHMWPE.

\section{ACKNOWLEDGEMENTS}

N. Camacho, G.C. Mondragón-Rodríguez, and J.M. González Carmona thank the support from the Mexican Council of Science and Technology (CONACYT) through its fellowship program Cátedras CONACYT. Thanks to the "1er simposio nacional de prótesis ortopédicas:el estatus actual en México".

\section{REFERENCIAS BIBLIOGRÁFICAS}

[1] J. Baena, J. Wu, and Z. Peng, "Wear Performance of UHMWPE and Reinforced UHMWPE Composites in Arthroplasty Applications: A Review," Lubricants, vol. 3, no. 2. pp. 413-436, 2015, doi: 10.3390/lubricants3020413.

[2] A. S. Ranawat and C. S. Ranawat, "The history of total knee arthroplasty," The Knee Joint. pp. 699-707, 2012, doi: 10.1007/978-2-287-99353-4_63.

[3] S. M. Kurtz et al., "International survey of primary and revision total knee replacement," Int. Orthop., vol. 35, no. 12, pp. 1783-1789, Dec. 2011.

[4] A. M. Kandahari, X. Yang, K. A. Laroche, A. S. Dighe, D. Pan, and Q. Cui, "A review of UHMWPE wear-induced 
osteolysis: the role for early detection of the immune response," Bone Research, vol. 4, no. 1. 2016, doi: 10.1038/boneres.2016.14.

[5] M. Nine, D. Choudhury, A. Hee, R. Mootanah, and N. Osman, "Wear Debris Characterization and Corresponding Biological Response: Artificial Hip and Knee Joints," Materials, vol. 7, no. 2. pp. 9801016, 2014, doi: 10.3390/ma7020980.

[6] M. C. S. Inacio, E. W. Paxton, S. E. Graves, R. S. Namba, and S. Nemes, "Projected increase in total knee arthroplasty in the United States - an alternative projection model," Osteoarthritis and Cartilage, vol. 25, no. 11. pp. 1797-1803, 2017, doi: 10.1016/j.joca.2017.07.022.

[7] L. Leitner et al., "Trends and Economic Impact of Hip and Knee Arthroplasty in Central Europe: Findings from the Austrian National Database," Sci. Rep., vol. 8, no. 1, p. 4707, Mar. 2018.

[8] E. M. B. del Prever, E. M. B. del Prever, A. Bistolfi, P. Bracco, and L. Costa, "UHMWPE for arthroplasty: past or future?," Journal of Orthopedics and Traumatology, vol. 10, no. 1. pp. 1-8, 2009, doi: 10.1007/s10195-008-0038-y.

[9] M. C. Sobieraj and C. M. Rimnac, "Ultra high molecular weight polyethylene: mechanics, morphology, and clinical behavior," J. Mech. Behav. Biomed. Mater., vol. 2, no. 5, pp. 433-443, Oct. 2009.

[10] B. P. Chang, H. M. Akil, R. B. Nasir, and A. Khan, "Optimization on wear performance of UHMWPE composites using response surface methodology," Tribology International, vol. 88. pp. 252-262, 2015, doi: 10.1016/j.triboint.2015.03.028.

[11] M. J. Martínez-Morlanes, P. Castell, V. Martínez-Nogués, M. T. Martinez, P. J.
Alonso, and J. A. Puértolas, "Effects of gamma-irradiation on UHMWPE/MWNT nanocomposites," Composites Science and Technology, vol. 71, no. 3. pp. 282-288, 2011 , doi: 10.1016/j.compscitech.2010.11.013.

[12] Y. Xue, W. Wu, O. Jacobs, and B. Schädel, "Tribological behaviour of UHMWPE/HDPE blends reinforced with multi-wall carbon nanotubes," Polymer Testing, vol. 25, no. 2. pp. 221-229, 2006, doi: 10.1016/j.polymertesting.2005.10.005.

[13] S. F. E, F. E. S., L. Shi, Z. G. Guo, and W. M. Liu, "The recent progress of tribological biomaterials," Biosurface and Biotribology, vol. 1, no. 2. pp. 81-97, 2015, doi: 10.1016/j.bsbt.2015.06.002.

[14] M. K. Musib, "A Review of the History and Role of UHMWPE as A Component in Total Joint Replacements," International Journal of Biological Engineering, vol. 1, no. 1. pp. 6-10, 2012, doi: 10.5923/j.ijbe.20110101.02.

[15] C. Fabry, C. Zietz, R. Dammer, and R. Bader, "12 Patterns of Wear in Total Knee Replacement," The Unhappy Total Knee Replacement. pp. 135-145, 2015, doi: 10.1007/978-3-319-08099-4_13.

[16]https://pdfs.semanticscholar.org/cc0e/7a e4c4f6022ef1011014b4d9740e802fb8c3.pdf (accessed May 20, 2020).

[17] G. W. Stachowiak, "Friction and Wear of Polymers, Ceramics and Composites in Biomedical Applications," Advances in Composite Tribology. pp. 509-557, 1993, doi: 10.1016/b978-0-444-89079-5.50018-0.

[18] P. Massin, "How does total knee replacement technique influence polyethylene wear?," Orthop. Traumatol. Surg. Res., vol. 103, no. 1S, pp. S21-S27, Feb. 2017. 
[19] J. Netter, J. Hermida, C. FloresHernandez, N. Steklov, M. Kester, and D. D'Lima, "Prediction of Wear in Crosslinked Polyethylene Unicompartmental Knee Arthroplasty," Lubricants, vol. 3, no. 2. pp. 381-393, 2015, doi: $10.3390 /$ lubricants3020381.

[20] M. Akagi et al., "Wear and toughness of crosslinked polyethylene for total knee replacements: a study using a simulator and small-punch testing," J. Orthop. Res., vol. 24, no. 10 , pp. 2021-2027, Oct. 2006.

[21] J. S. Bergström, C. M. Rimnac, and S. M. Kurtz, "Prediction of multiaxial mechanical behavior for conventional and highly crosslinked UHMWPE using a hybrid constitutive model," Biomaterials, vol. 24, no. 8, pp. 1365-1380, Apr. 2003.

[22] S. H. User, "American Joint Replacement Registry Releases 2018 Annual Report." http://blog.ajrr.net/american-jointreplacement-registry-releases-2018-annualreport (accessed May 20, 2020).

[23] R. Lerf, D. Zurbrügg, and D. Delfosse, "Use of vitamin E to protect crosslinked UHMWPE from oxidation," Biomaterials, vol. 31, no. 13, pp. 3643-3648, May 2010.

[24] E. Oral, C. Godleski Beckos, A. S. Malhi, and O. K. Muratoglu, "The effects of high dose irradiation on the cross-linking of vitamin E-blended ultrahigh molecular weight polyethylene," Biomaterials, vol. 29, no. 26, pp. 3557-3560, Sep. 2008.

[25] E. Oral, A. Neils, and O. K. Muratoglu, "High vitamin E content, impact resistant UHMWPE blend without loss of wear resistance," Journal of Biomedical Materials Research Part B: Applied Biomaterials, vol. 103, no. 4. pp. 790-797,
2015, doi: 10.1002/jbm.b.33256.

[26] B.-P. Chang, H. M. Akil, and R. B. M. Nasir, "Comparative study of micro- and nano-ZnO reinforced UHMWPE composites under dry sliding wear," Wear, vol. 297, no. 1-2. pp. 1120-1127, 2013, doi: 10.1016/j.wear.2012.11.083.

[27] B. P. Chang, H. M. Akil, and R. M. Nasir, "Mechanical and Tribological Properties of Zeolite-reinforced UHMWPE Composite for Implant Application," Procedia Engineering, vol. 68. pp. 88-94, 2013, doi: 10.1016/j.proeng.2013.12.152.

[28] K. Plumlee and C. J. Schwartz, "Improved wear resistance of orthopedic UHMWPE by reinforcement with zirconium particles," Wear, vol. 267, no. 5-8. pp. 710717, 2009, doi: 10.1016/j.wear.2008.11.028.

[29] L. Fang, Y. Leng, and P. Gao, "Processing and mechanical properties of HA/UHMWPE nanocomposites," Biomaterials, vol. 27, no. 20, pp. 3701-3707, Jul. 2006.

[30] L. Fang, P. Gao, and Y. Leng, "High strength and bioactive hydroxyapatite nanoparticles reinforced ultrahigh molecular weight polyethylene," Composites Part B: Engineering, vol. 38, no. 3. pp. 345-351, 2007 , doi: 10.1016/j.compositesb.2006.05.004.

[31] N. T. Dintcheva et al., "Multifunctional hindered amine light stabilizersfunctionalized carbon nanotubes for advanced ultra-high molecular weight Polyethylene-based nanocomposites," Composites Part B: Engineering, vol. 82. pp. 196-204, 2015, doi: 10.1016/j.compositesb.2015.07.017.

[32] A. Fonseca, S. Kanagaraj, M. S. A. Oliveira, and J. A. O. Simões, "Enhanced UHMWPE Reinforced with MWCNT through 
Mechanical Ball-Milling," Defect and Diffusion Forum, vol. 312-315. pp. 12381243, 2011, doi: 10.4028/www.scientific.net/ddf.312315.1238 .

[33] M. Pöllänen, S. Pirinen, M. Suvanto, and T. T. Pakkanen, "Influence of carbon nanotube-polymeric compatibilizer masterbatches on morphological, thermal, mechanical, and tribological properties of polyethylene," Compos. Sci. Technol., vol. 71, no. 10, pp. 1353-1360, Jul. 2011.

[34] S. L. Ruan, P. Gao, X. G. Yang, and T. X. Yu, "Toughening high performance ultrahigh molecular weight polyethylene using multiwalled carbon nanotubes," Polymer, vol. 44, no. 19. pp. 5643-5654, 2003, doi: 10.1016/s0032-3861(03)00628-1.

[35] P. S. R. Sreekanth, P. S. Rama Sreekanth, and S. Kanagaraj, "Influence of multi walled carbon nanotubes reinforcement and gamma irradiation on the wear behaviour of UHMWPE," Wear, vol. 334335. pp. 82-90, 2015, doi: 10.1016/j.wear.2014.12.014.

[36] S. Suñer, C. L. Bladen, N. Gowland, J. L. Tipper, and N. Emami, "Investigation of wear and wear particles from a UHMWPE/multi-walled carbon nanotube nanocomposite for total joint replacements," Wear, vol. 317, no. 1-2. pp. 163-169, 2014, doi: 10.1016/j.wear.2014.05.014.

[37] Y.-S. Zoo, J.-W. An, D.-P. Lim, and D.-S. Lim, "Effect of Carbon Nanotube Addition on Tribological Behavior of UHMWPE," Tribology Letters, vol. 16, no. 4. pp. 305-309, 2004, doi: 10.1023/b:tril.0000015206.21688.87.

[38] J. A. Puértolas and S. M. Kurtz, "Evaluation of carbon nanotubes and graphene as reinforcements for UHMWPE- based composites in arthroplastic applications: A review," J. Mech. Behav. Biomed. Mater., vol. 39, pp. 129-145, Nov. 2014.

[39] D. Lahiri, F. Hec, M. Thiesse, A. Durygin, C. Zhang, and A. Agarwal, "Nanotribological behavior of graphene nanoplatelet reinforced ultra high molecular weight polyethylene composites," Tribology International, vol. 70. pp. 165-169, 2014, doi: 10.1016/j.triboint.2013.10.012.

[40] P.-G. Ren, Y.-Y. Di, Q. Zhang, L. Li, H. Pang, and Z.-M. Li, "Composites of Ultrahigh-Molecular-Weight Polyethylene with Graphene Sheets and/or MWCNTs with Segregated Network Structure: Preparation and Properties," Macromolecular Materials and Engineering, vol. 297, no. 5. pp. 437443, 2012, doi: 10.1002/mame.201100229.

[41] A. Chih, A. Ansón-Casaos, and J. A. Puértolas, "Frictional and mechanical behaviour of graphene/UHMWPE composite coatings," Tribology International, vol. 116. pp. 295-302, 2017, doi: 10.1016/j.triboint.2017.07.027.

[42] Z. You and D. Li, "The dynamical viscoelasticity and tensile property of new highly filled charcoal powder/ultra-high molecular weight polyethylene composites," Materials Letters, vol. 112. pp. 197-199, 2013, doi: 10.1016/j.matlet.2013.09.013.

[43] M. C. Sobieraj and C. M. Rimnac, "Ultra high molecular weight polyethylene: mechanics, morphology, and clinical behavior," J. Mech. Behav. Biomed. Mater., vol. 2, no. 5, pp. 433-443, Oct. 2009.

[44] B. Hunt and T. Joyce, "A Tribological Assessment of Ultra High Molecular Weight Polyethylene Types GUR 1020 and GUR 1050 for Orthopedic Applications," Lubricants, vol. 4, no. 3. p. 25, 2016, doi: 


\subsection{0/lubricants4030025.}

[45] S. M. Kurtz, The UHMWPE Handbook: Ultra-High Molecular Weight Polyethylene in Total Joint Replacement. Elsevier, 2004.

[46] S. Affatato, A. Ruggiero, and M. Merola, "Advanced biomaterials in hip joint arthroplasty. A review on polymer and ceramics composites as alternative bearings," Composites Part B: Engineering, vol. 83. pp. 276-283, 2015, doi: 10.1016/j.compositesb.2015.07.019.

[47] K. S. Kanaga Karuppiah et al., "Friction and wear behavior of ultra-high molecular weight polyethylene as a function of polymer crystallinity," Acta Biomater., vol. 4, no. 5, pp. 1401-1410, Sep. 2008.

[48] M. Hussain et al., "Ultra-HighMolecular-Weight-Polyethylene (UHMWPE) as a Promising Polymer Material for Biomedical Applications: A Concise Review," Polymers , vol. 12, no. 2, Feb. 2020, doi: 10.3390/polym 12020323 .

[49] M. Khan, K. Osman, G. Green, and F. S. Haddad, "The epidemiology of failure in total knee arthroplasty," The Bone \& Joint Journal, vol.98-B, no. 1_Supple_A. pp. 105112, 2016, doi: 10.1302/0301620x.98b1.36293.

[50] A. Postler, C. Lützner, F. Beyer, E. Tille, and J. Lützner, "Analysis of Total Knee Arthroplasty revision causes," BMC Musculoskelet. Disord., vol. 19, no. 1, p. 55, Feb. 2018.

[51] C. L. Brockett, S. Carbone, J. Fisher, and L. M. Jennings, "Influence of conformity on the wear of total knee replacement: An experimental study," Proc. Inst. Mech. Eng. H, vol. 232, no. 2, pp. 127-134, Feb. 2018.
[52] S. Liza, A S M, A. A. Abbas, and H. H. Masjuki, "Failure analysis of retrieved UHMWPE tibial insert in total knee replacement," Engineering Failure Analysis, vol. 18, no. 6. pp. 1415-1423, 2011, doi: 10.1016/j.engfailanal.2011.04.001.

[53] D. Bitar and J. Parvizi, "Biological response to prosthetic debris," World J. Orthop., vol. 6, no. 2, pp. 172-189, Mar. 2015.

[54] Z. Gu, B. Huang, Y. Li, M. Tian, L. $\mathrm{Li}$, and $\mathrm{X}$. Yu, "Strontium-doped calcium polyphosphate/ultrahigh molecular weight polyethylene composites: A new class of artificial joint components with enhanced biological efficacy to aseptic loosening," Mater. Sci. Eng. C Mater. Biol. Appl., vol. 61, pp. 526-533, Apr. 2016.

[55] J. Fisher et al., "A novel method for the prediction of functional biological activity of polyethylene wear debris," Proc. Inst. Mech. Eng. H, vol. 215, no. 2, pp. 127-132, 2001.

[56]https://www.ors.org/Transactions/63/203 6.pdf (accessed Sep. 27, 2020).

[57] C. H. Won, S. Rohatgi, M. J. Kraay, V. M. Goldberg, and C. M. Rimnac, "Effect of resin type and manufacturing method on wear of polyethylene tibial components," Clin. Orthop. Relat. Res., no. 376, pp. 161171, Jul. 2000.

[58] E. Oral, K. K. Wannomae, N. Hawkins, W. H. W. H. Harris, and O. K. O. K. Muratoglu, "Alpha-tocopherol-doped irradiated UHMWPE for high fatigue resistance and low wear," Biomaterials, vol. 25, no. 24, pp. 5515-5522, Nov. 2004.

[59]https://connect.ajrr.net/hubfs/PDFs\%20a nd\%20PPTs/AAOS_AJRR_2019_Annual_R eport_Update_FINAL_150DPI.pdf?hsCtaTr 
acking $=1 \mathrm{~d} 80 \mathrm{e} 9 \mathrm{fa}-66 \mathrm{fe}-4525-\mathrm{a} 5 \mathrm{cb}-$

15c30ec19a1f\%7C8becda93-a51e-41cc-

bcfa-ca9130c1add6 (accessed Sep. 29, 2020).

[60] T. Liu, A. Eyler, and W.-H. Zhong, "Simultaneous improvements in wear resistance and mechanical properties of UHMWPE nanocomposite fabricated via a facile approach," Materials Letters, vol. 177. pp. 2016, doi: 10.1016/j.matlet.2016.04.072.

[61] G. Lewis, "Properties of crosslinked ultra-high-molecular-weight polyethylene," Biomaterials, vol. 22, no. 4. pp. 371-401, 2001, doi: 10.1016/s0142-9612(00)00195-2.

[62] https://www.ors.org/Transactions/63/203 6.pdf (accessed Sep. 29, 2020).

[63] M. J. Martínez-Morlanes, P. Castell, P. J. Alonso, M. T. Martinez, and J. A. Puértolas, "Multi-walled carbon nanotubes acting as free radical scavengers in gammairradiated ultrahigh molecular weight polyethylene composites," Carbon, vol. 50, no. 7. pp. 2442-2452, 2012, doi: 10.1016/j.carbon.2012.01.066.

[64] S. M. Kurtz, O. K. Muratoglu, M. Evans, and A. A. Edidin, "Advances in the processing, sterilization, and crosslinking of ultra-high molecular weight polyethylene for total joint arthroplasty," Biomaterials, vol. 20, no. 18, pp. 1659-1688, Sep. 1999.

[65] S. M. Kurtz, M. L. Villarraga, M. P. Herr, J. S. Bergström, C. M. Rimnac, and A. A. Edidin, "Thermomechanical behavior of virgin and highly crosslinked ultra-high molecular weight polyethylene used in total joint replacements," Biomaterials, vol. 23, no. 17, pp. 3681-3697, Sep. 2002.

[66] K. W. Greer, R. S. King, and F. W. Chan, "The Effects of Raw Material, Irradiation Dose, and Irradiation Source on
Crosslinking of UHMWPE," Jaina, vol. 1, no. 1, pp. 1-11, Jan. 2004, Accessed: Sep. 29, 2020. [Online].

[67] H. Haider et al., "Does vitamin Estabilized ultrahigh-molecular-weight polyethylene address concerns of crosslinked polyethylene in total knee arthroplasty?," J. Arthroplasty, vol. 27, no. 3, pp. 461-469, Mar. 2012.

[68] S. M. Kurtz, UHMWPE Biomaterials Handbook: Ultra High Molecular Weight Polyethylene in Total Joint Replacement and Medical Devices. William Andrew, 2015.

[69] C. Vaidya, E. Alvarez, J. Vinciguerra, D. A. Bruce, and J. D. DesJardins, "Reduction of total knee replacement wear with vitamin $E$ blended highly cross-linked ultra-high molecular weight polyethylene," Proc. Inst. Mech. Eng. H, vol. 225, no. 1, pp. 1-7, Jan. 2011.

[70] K. Iwakiri et al., "In vivo comparison of wear particles between highly crosslinked polyethylene and conventional polyethylene in the same design of total knee arthroplasties," J. Biomed. Mater. Res. B Appl. Biomater., vol. 91, no. 2, pp. 799-804, Nov. 2009.

[71] S. M. Kurtz, J. Dumbleton, R. S. Siskey, A. Wang, and M. Manley, "Trace concentrations of vitamin $E$ protect radiation crosslinked UHMWPE from oxidative degradation," J. Biomed. Mater. Res. A, vol. 90, no. 2, pp. 549-563, Aug. 2009.

[72] S. M. Kurtz, D. Mazzucco, C. M. Rimnac, and D. Schroeder, "Anisotropy and oxidative resistance of highly crosslinked UHMWPE after deformation processing by solid-state ram extrusion," Biomaterials, vol. 27, no. 1, pp. 24-34, Jan. 2006.

[73] C. Wolf, T. Krivec, J. Blassnig, K. 
Lederer, and W. Schneider, "Examination of the suitability of alpha-tocopherol as a stabilizer for ultra-high molecular weight polyethylene used for articulating surfaces in joint endoprostheses," J. Mater. Sci. Mater. Med., vol. 13, no. 2, pp. 185-189, Feb. 2002.

[74] N. Tomita, T. Kitakura, N. Onmori, Y. Ikada, and E. Aoyama, "Prevention of fatigue cracks in ultrahigh molecular weight polyethylene joint components by the addition of vitamin E," J. Biomed. Mater. Res., vol. 48, no. 4, pp. 474-478, 1999.

[75] S. Teramura, H. Sakoda, T. Terao, M. M. Endo, K. Fujiwara, and N. Tomita, "Reduction of wear volume from ultrahigh molecular weight polyethylene knee components by the addition of vitamin E," J. Orthop. Res., vol. 26, no. 4, pp. 460-464, Apr. 2008.

[76] E. Oral and O. K. Muratoglu, "Vitamin E diffused, highly crosslinked UHMWPE: a review," Int. Orthop., vol. 35, no. 2, pp. 215-223, Feb. 2011.

[77] J.-Z. Xu, K. K. Wannomae, O. K. Muratoglu, and E. Oral, "Increased oxidative protection by high active vitamin $E$ content and partial radiation crosslinking of UHMWPE," J. Orthop. Res., vol. 36, no. 7, pp. 1860-1867, Jul. 2018.

[78] E. Oral, S. D. Christensen, A. S. Malhi, K. K. Wannomae, and O. K. Muratoglu, "Wear resistance and mechanical properties of highly cross-linked, ultrahighmolecular weight polyethylene doped with vitamin E," J. Arthroplasty, vol. 21, no. 4, pp. 580-591, Jun. 2006.

[79] G. Sui, W. H. Zhong, X. Ren, X. Q. Wang, and X. P. Yang, "Structure, mechanical properties and friction behavior of UHMWPE/HDPE/carbon nanofibers," Materials Chemistry and Physics, vol. 115, no. 1. pp. 404-412, 2009, doi: 10.1016/j.matchemphys.2008.12.016.

[80] F. M. Michael et al., "Effect of nanofillers on the physico-mechanical properties of load bearing bone implants," Mater. Sci. Eng. C Mater. Biol. Appl., vol. 67, pp. 792-806, Oct. 2016.

[81] P. S. Rama Sreekanth and S. Kanagaraj, "Assessment of bulk and surface properties of medical grade UHMWPE based nanocomposites using Nanoindentation and microtensile testing," J. Mech. Behav. Biomed. Mater., vol. 18, pp. 140-151, Feb. 2013.

[82] D. Xiong, J. Lin, D. Fan, and Z. Jin, "Wear of nano-TiO2/UHMWPE composites radiated by gamma ray under physiological saline water lubrication," J. Mater. Sci. Mater. Med., vol. 18, no. 11, pp. 2131-2135, Nov. 2007.

[83] G. Guofang, Y. Huayong, and F. Xin, "Tribological properties of kaolin filled UHMWPE composites in unlubricated sliding," Wear, vol. 256, no. 1-2. pp. 88-94, 2004, doi: 10.1016/s0043-1648(03)00394-6.

[84] G. Gong, "TRIBOLOGICAL STUDIES OF KAOLIN FILLED UHMWPE COMPOSITES IN SLIDING AGAINST STEEL LUBRICATED WITH WATER," Chinese Journal of Mechanical Engineering, vol. 38, no. supp. p. 172, 2002, doi: 10.3901/jme.2002.supp.172.

[85] D. L. P. Macuvele et al., "Advances in ultra high molecular weight polyethylene/hydroxyapatite composites for biomedical applications: A brief review," Mater. Sci. Eng. C Mater. Biol. Appl., vol. 76, pp. 1248-1262, Jul. 2017.

[86] C. J. Schwartz, S. Bahadur, and S. K. Mallapragada, "Effect of crosslinking and Pt- 
$\mathrm{Zr}$ quasicrystal fillers on the mechanical properties and wear resistance of UHMWPE for use in artificial joints," Wear, vol. 263, no. 7-12. pp. 1072-1080, 2007, doi: 10.1016/j.wear.2006.10.023.

[87] A. Ruggiero, R. D’Amato, and E. Gómez, "Experimental analysis of tribological behavior of UHMWPE against AISI420C and against $\mathrm{TiAl}_{6} V_{4}$ alloy under dry and lubricated conditions," Tribology International, vol. 92. pp. 154-161, 2015, doi: 10.1016/j.triboint.2015.06.005.

[88] A. Golchin, A. Wikner, and N. Emami, "An investigation into tribological behaviour of multi-walled carbon nanotube/graphene oxide reinforced UHMWPE in water lubricated contacts," Tribology International, vol. 95. pp. 156-161, 2016, doi: 10.1016/j.triboint.2015.11.023.

[89] Y. Liu and S. K. Sinha, "Wear performances and wear mechanism study of bulk UHMWPE composites with nacre and CNT fillers and PFPE overcoat," Wear, vol. 300, no. 1-2, pp. 44-54, Mar. 2013.

[90] B. M. Amoli, B. Meschi Amoli, S. A. Ahmad Ramazani, and H. Izadi, "Preparation of ultrahigh-molecular-weight polyethylene/carbon nanotube nanocomposites with a Ziegler-Natta catalytic system and investigation of their thermal and mechanical properties," Journal of Applied Polymer Science, vol. 125, no. S1. pp. E453-E461, 2012, doi: 10.1002/app.36368.

[91] J. A. Puértolas and S. M. Kurtz, "UHMWPE Matrix Composites," UHMWPE Biomaterials Handbook. pp. 369-397, 2016, doi: 10.1016/b978-0-323-35401-1.00021-1.

[92] N. Camacho, E. A. Franco-Urquiza, and S. W. Stafford, "Wear performance of multiwalled carbon nanotube-reinforced ultra-high molecular weight polyethylene composite," Advances in Polymer Technology, vol. 37, no. 6. pp. 2261-2269, 2018, doi: 10.1002/adv.21885.

[93] S. R. Bakshi, J. E. Tercero, and A. Agarwal, "Synthesis and characterization of multiwalled carbon nanotube reinforced ultra high molecular weight polyethylene composite by electrostatic spraying technique," Composites Part A: Applied Science and Manufacturing, vol. 38, no. 12. pp. 2493-2499, 2007, doi: 10.1016/j.compositesa.2007.08.004.

[94] R. M. Kumar, R. Manoj Kumar, S. K. Sharma, B. V. Manoj Kumar, and D. Lahiri, "Effects of carbon nanotube aspect ratio on strengthening and tribological behavior of ultra high molecular weight polyethylene composite," Composites Part A: Applied Science and Manufacturing, vol. 76. pp. 6272, 2015, doi: 10.1016/j.compositesa.2015.05.007.

[95] S. Yousef, A. Visco, G. Galtieri, D. Nocita, and C. Espro, "Wear behaviour of UHMWPE reinforced by carbon nanofiller and paraffin oil for joint replacement," Mater. Sci. Eng. C Mater. Biol. Appl., vol. 73, pp. 234-244, Apr. 2017.

[96] S. Kanagaraj, M. S. A. Oliveira, and J. A. de Oliveira Simões, "Tribology of biocomposites," Biomedical Composites. pp. 441-464, 2010, doi: 10.1533/9781845697372.3.441.

[97] N. Camacho, S. Stafford, K. Garza, R. Suro, and K. Barron, "Ultra-High Molecular Weight Polyethylene Reinforced with Multiwall Carbon Nanotubes: In Vitro Biocompatibility Study Using MacrophageLike Cells," Lubricants, vol. 3, no. 3. pp. 597610, 2015, doi: 10.3390/lubricants3030597.

[98] N. T. Dintcheva et al., "Multi- 
functional polyhedral oligomeric silsesquioxane-functionalized carbon nanotubes for photo-oxidative stable UltraHigh Molecular Weight Polyethylene-based nanocomposites," European Polymer Journal, vol. 75. pp. 525-537, 2016, doi: 10.1016/j.eurpolymj.2016.01.002.

[99] S. Santangelo et al., "A safer and flexible method for the oxygen functionalization of carbon nanotubes by nitric acid vapors," Applied Surface Science, vol. 303. pp. 446-455, 2014, doi: 10.1016/j.apsusc.2014.03.023.

[100] A. V. Maksimkin et al., "Bulk oriented nanocomposites of ultrahigh molecular weight polyethylene reinforced with fluorinated multiwalled carbon nanotubes with nanofibrillar structure," Composites Part B: Engineering, vol. 94. pp. 292-298, 2016, doi: 10.1016/j.compositesb.2016.03.061.

[101] M. A. Samad, M. Abdul Samad, and S. K. Sinha, "Mechanical, thermal and tribological characterization of a UHMWPE film reinforced with carbon nanotubes coated on steel," Tribology International, vol. 44, no. 12. pp. 1932-1941, 2011, doi: 10.1016/j.triboint.2011.08.001.

[102] N. T. Dintcheva et al., " $\alpha$ Tocopherol-induced radical scavenging activity in carbon nanotubes for thermooxidation resistant ultra-high molecular weight polyethylene-based nanocomposites," Carbon, vol. 74. pp. 14-21, 2014, doi: 10.1016/j.carbon.2014.02.074.

[103] X. Qiao, M. Na, P. Gao, and K. Sun, "Halloysite nanotubes reinforced ultrahigh molecular weight polyethylene nanocomposite films with different filler concentration and modification," Polymer Testing, vol. 57. pp. 133-140, 2017, doi: 10.1016/j.polymertesting.2016.11.024.

[104] L. Fang, Y. Leng, and P. Gao, "Processing of hydroxyapatite reinforced ultrahigh molecular weight polyethylene for biomedical applications," Biomaterials, vol. 26, no. 17, pp. 3471-3478, Jun. 2005.

[105] S. Sharma, J. Bijwe, and S. Panier, "Assessment of potential of nano and microsized boron carbide particles to enhance the abrasive wear resistance of UHMWPE," Composites Part B: Engineering, vol. 99. pp. 312-320, 2016, doi: 10.1016/j.compositesb.2016.06.003.

[106] S. V. Panin, L. A. Kornienko, M. V. Chaikina, V. P. Sergeev, L. R. Ivanova, and S. V. Shilko, "Nano- and Micro-Structured UHMWPE Composites Filled With Hydroxyapatite Irradiated by Nitrogen Ion Beams for Bio-Medical Applications," Russian Physics Journal, vol. 56, no. 10. pp. 1137-1143, 2014, doi: 10.1007/s11182-0140153-6 